\title{
The Moral Value in The Folklore of Kl Ageng Wonolelo Widodomartani, Ngemplak, Sleman, Special Region Province of Yogyakarta (Literature Reception Review)
}

\author{
Sundari \\ \{sundari@staff.uns.ac.id\} \\ Sastra Daerah FIB UNS
}

\begin{abstract}
The Moral Value in The Folklore of Ki Ageng Wonolelo at Widodomartani, Ngemplak, Sleman, Special Region Province of Yogyakarta (Literature Review). This study aims to find the moral value in the Folklore of Ki Ageng Wonolelo. The analytical method used is descriptive qualitative by Literature Reception. The data used are spoken data such as interviews and primary data sources, namely informants, while secondary data are references and books that relevant to research topic. The moral values of The Folklore of Ki Ageng Wonolelo are 15 moral values consisting of religious, honest, tolerance, discipline, hard work, creative, independent, democratic, spirit of nationality, nationalism, rewarding achievement, friendly/communicative, peace-loving, social care, and responsibility.
\end{abstract}

Keywords: Literature, Ki Ageng Wonolelo, Literature Reception

\section{Introduction}

Ki Ageng Wonolelo is an ancestral figure who is considered as the pioneer of Pondok Wonolelo. Ki Ageng Wonolelo with the real name Jumadi Geno, is a descendant of the King Brawijaya $\mathrm{V}$ one of the characters propagator of Islam in the kingdom of Mataram at the same timel . At that time, he was living in Dusun $\mathrm{P}$ ondok Wonolelo, and became a person with high mysticism. Pondok Wonolelo is located in Widodomartani, Ngemplak, Sleman, Yogyakarta. In the Folklore of Ki Ageng Wonolelo, there is a tradition of the traditional ceremony of saparan.

James Danandjaja quoted Alan Dundes' opinion in his book, folklore originates from two basic words, namely folk and lore. Folk is a group of people who have physical, social and cultural identifying characteristics, so that they can be distinguished from other groups. Meanwhile, lore is a folk tradition, namely as a culture from generation to generation by spoken or example by gestures or reminder tool. Folklore is the result of a collective culture is inherited from generation to generation in any forms, traditionally in different versions either verbally or examples that accompanied gestures or reminder tool4.

The Saparan traditional ceremony which is part of the Folklore of Ki Ageng Wonolelo has been known by some people of Pondok Wonolelo, Widodomartani, Ngemplak, Sleman, Yogyakarta, which was held in the month of Sapar. The Saparan Wonolelo Ceremony is held 
in the form of Ki Ageng Wonolelo procession. The top event, there is a heirloom parade and apem distribution to people were held. Apem cake has a meaning for local residents, namely "afuwun" which means forgiveness, with the intention of the children and grandchildren to improve the forgiveness to God Almighty. The holding of this ceremony is important for the socio-cultural destruction of the community due to its function is strengthening norms and prevailing cultural values.

The Literature Reception comes from the word recipere (Latin) which means receiver and reception (English) which means welcoming the reader. Reception in a broad sense can be defined as text classification, giving meaning to works, so that they can respond to them. The response referred to is not made between the work and a reader, but the reader as a historical process or a reader in a certain period. A Teeuw considers the study of literary reception as very appropriate for Indonesian literature due to Indonesia has literary repertoire, especially old literature with high diversity. Reception of Literature means that the reader's response, historical life of literature or literary works cannot exist without the active participation of the recipient [1].

Aesthetic Reception or Literary Reception gives main attention to readers of literary works between the triangular fabric of writers, literary works and the reading community [2]. One form of literary work in the form of folklore, has a sign or meaning that is accepted by society. Then comes the horizon of hope which is based on the differences in understanding of each society. Hope horizon is an interaction between literary works and readers or devotee and interpretations in society. In the study on life cycle folklore, people are asked to respond to literary works in the form of oral traditions then the results of the community's responses are analyzed qualitatively to get the results of the community's responses which are influenced by many factors, including socio-cultural background, educational level, experience level and age of the community.

The traditional ceremony is one of the traditional community traditions that are still considered to have values that are relevant to the needs of the supporting community. Apart from being a human effort to be able to relate to the spirits of the ancestors, it is also a manifestation of the human ability to actively adapt to nature or its environment in a broad sense. This ceremony has the aim of garnering a sense of solidarity and unity as well as a means of strengthening existing socio-cultural values and prevailing in society.

Traditional traditional ceremonies are an important part of the culture of the people of each region due to they are social activities that involve community members in an effort to achieve mutual safety which is conducted from many generations and held at certain times to convey messages from moral value. Moral is the values of human behavior which are measured according to good and bad through the measurement of religious norms, legal norms, customs norms and manners. Moral is classified into two forms, namely pituduh (wejangan), which is to give advice in the form of advice and pepali (wewaler), which is a prohibition to do bad deeds [3]

According to the Ministry of National Education's Curriculum Center in Suyadi's Book [4], the importance of character is classified to be eighteen pillars of character education, namely religious, honesty, tolerance, discipline and so on. Broadly speaking, ethics is an attitude that encourages people to do something based on their instincts, thoughts, and intellect. Moral differentiates humans and animals. Literary works can be used to find out the human life [5]. One of the impacts of globalization is in the cultural aspects that different cultures are increasingly coming into contact with one another [6].

This traditional ceremony has ethical values that explain do's and dont's in life. Given the importance of moral values in the Folklore of Ki Ageng Wonolelo, it is expected that the 
community can capture, live and practice these moral values. As for the research problem formulation, what are the moral values contained in the Folklore of Ki Ageng Wonolelo in Widodomartani, Ngemplak, Sleman, Special Region of Yogyakarta (Literature Reception Review)?

\section{Research Methods}

The method of study used descriptive qualitative study for literature study. Qualitative research is research that is natural in nature and produces descriptive data in the form of written or oral words from people, behavior, or other data that can be observed by researchers [7]. Data analysis aims to simplify data into forms that are easier to read and interpret [8].

The method used in this study is a synchronous literary reception method, namely analyzing the responses of contemporary information using interview techniques. The study was conducted in Pondok Wonolelo, Widodomartani, Ngemplak, Sleman, Yogyakarta. The primary data source is interviewing informants, the results of interview observations are notes and recordings. Meanwhile, the secondary data sources were taken through references and books relevant to topic of study.

Folklore is a literary work that was born and developed in traditional societies and distributed in the form of relatively fixed or in raw form distributed among particular collectively in a long time.

\section{Results and Discussion}

\section{Moral Values in the Folklore of Ki Ageng Wonolelo}

The Folklore of Ki Ageng Wonolelo contains useful messages in which there are the moral value of a prominent Muslim propagator. The language employed by a community is considered as the reflection of the entire culture of the community. Thus, many experts consider that culture cannot be separated from the language and its utilization in the community [9]. The values of character that appear in Ki Ageng Wonolelo's folklore can be developed in the community for the development of the next generation in sustainable manner. The following are forms of moral values that the writer found in Ki Ageng Wonolelo's story include:

\section{Religious}

The religious values in the folktale of Ki Ageng Wonolelo at Pondok Wonolelo describe a student of his grandfather who studied religion and apply his knowledge. Ki Ageng Wonolelo is an obedient and obedient figure in conducting the religious teachings of Islam aimed at conducting prayer as a religious pillar. The religious values shown by the figure Ki Ageng Wonolelo are as follows:

Quote:

"Saksampunipun sholat subuh, lajeng bandile diputer-puterke Syeh Jumadigeno sambil membaca Bismillahi Allahhuakbar".

Translate :

"After performing the dawn prayer, then the Bandil was played by Syeh Jumadigeno while saying Bismillahi Allahhuakbar" 
The above quote, the figure of Ki Ageng Wonolelo shows himself as someone who is obedient person in religion. Local genius emerge into: value, norm, faith, custom, eel. They have special meaning and function [10]. Myth is a story that provides certain guidelines and directions to a group of people [11].

\section{Honest}

The value of honesty in Ki Ageng Wonolelo's folklore can be seen implicitly from the figure of Ki Ageng Wonolelo who has honorable character.

This can be seen from the speech as follows:

Quote.

"Amargi kathah sing ngelmu agama, sinau ngaji wonten mriki saking pundipundi kathah nginep mriki lajeng Ki Ageng Wonolelo mbangun pondok dingge santrinipun Ki Ageng Wonolelo".

Translate :

"Because there are many who study religion and study the Koran here, wherever they come they stay here. In he following day, Ki Ageng Wonolelo built a place for his students".

This indicates the honest attitude and actions of Ki Ageng Wonolelo because he conduct the mandate that had been conveyed by his grandfather and did not divert the knowledge he had.

\section{Tolerance}

The tolerance value in the folklore of Ki Ageng Wonolelo illustrates the mutual respect that exists between the people at Pondok Wonolelo, this can be seen at the time of the traditional ceremony to reveal the value of tolerance in the following speech:

Quote:

"Yen upacara Saparan to mbak ana gunungan apem kuwi bobote sak ton, Iha kuwi saben rumah warga Pondok Wonolelo gawe apem mbak, mengko dikumpulke bar kuwi ditata dadi gunungan mbak, itu saben omah mbak kuwi muslim apa dudu apa asli orang sini apa dudu tetep ya melu gawe mbak."

Translate :

"For the Saparan ceremony, there is a mountain of apem, it weighs about one ton, now that every resident's house in Pondok Wonolelo makes apem, sis, later the apem is collected and after that it is arranged to be a mountain. All people whether they are moslem or not, they help to make apem".

They do not look at their religion, ethnicity, customs and race for the sake of the traditional ceremony goes well.

\section{Discipline}

The value of discipline in the folklore of Ki Ageng Wonolelo is reflected in the figure of Ki Ageng Wonolelo who behaves orderly and obeys the rules of Islam. Ki Ageng Wonolelo always performs prayers wherever he is. This is according to what is said as follows:

Quote:

"Saksampunipun sholat Subuh, bandile diputer-puterke Syeh Jumadigeno sambil membaca Bismillahi Allahuakbar".

Translate

"After performing the Fajr prayer, Syeh Jumadigeno played the Bandil while reading Bismillahi Allahuakbar". 
Ki Ageng Wonolelo showed discipline in performing prayers. Prayer is a rule that must be carried out by every Muslim, in this case Ki Ageng Wonolelo is proven to be obedient to Islamic religious rules.

\section{Hard work}

The value of hard work contained in the folklore of Ki Ageng Wonolelo can be seen that Ki Ageng Wonolelo is a hard worker and can face all the obstacles he face in life. This can be seen from the following speech.

Quote:

"Ki Ageng Wonolelo niku sing mbikak desa mriki mbak, mriki riyin hutan alas mbak".

Translate :

"Ki Ageng Wonolelo opened this village, sis, it used to be a jungle, sis".

The hardworking attitude of Ki Ageng Wonolelo is shown when he can get through obstacle well.

\section{Creative}

The creative value contained in the folklore of Ki Ageng Wonolelo can be seen in an innovative way of thinking, where Ki Ageng Wonolelo built a cottage to stay for his students, and he also built a Trajumas house and Mosque. This is shown by the following narrative:

Quote:

"Riyin kan Ki Ageng niku tiyang pertama sing wonten mriki mbak, bibar babat hutan Malelo, Ki Ageng damel omah Trajumas sing bentuke limas saka gurune enem Nah twang mriki nyebat niku omah tiban amerga tiba-tiba ana wae mengkana mbak. Bar bangun omah Trajumas mauke mbangun msajid neng sak kidule omah Trajumas mbak, supaya bisa nggo sholat.

Translate :

"Previously, Ki Ageng Wonolelo was the first person here, sis, after cut through the Malelo forest, Ki Ageng Wonolelo made Trajumas' pyramid-shaped house consisting of six teachers. Now the people here call this house a tiban house because suddenly Just like that, sis. After building the Trajumas house earlier, then building a mosque to the south of the Trajumas house, so you can pray."

\section{Independent}

The independent value found in the folklore of Ki Ageng Wonolelo, namely that all the obstacles he went through in his life were conducted by Ki Ageng Wonolelo alone. As long as he wandered, he never depended on other people. He was able to not show his weakness or inability to face the obstacles he went through despite the sign of Syeh Wasibageno.

\section{Democratic}

The democratic values contained in the folklore of Ki Ageng Wonolelo can be seen from the attitudes and behavior of Ki Ageng Wonolelo who is a leader or teacher for his students who want to learn religious knowledge from him. This can be seen in the following utterances.

Quote:

$\ldots$

Translate :

"Because there are many who study religion and study the Koran here, wherever they come they stay here and then Ki Ageng Wonolelo built the cottage for his students " 
The figure of a teacher or leader for his students and who teaches religious knowledge at the same time thinking about the needs of his students to live. This democratic leader was liked by his followers.

\section{Spirit of nationality}

The value of the national spirit in the folklore of Ki Ageng Wonolelo was stated when Ki Ageng Wonolelo cut through the Malelo forest and built houses, mosques and cottages for community. Ki Ageng Wonolelo's heroic spirit and always puts the needs of many people first. This can be seen from the speech as follows:

Quote:

...

Translate :

"Because there are many people who study religion and study the Koran here, wherever they come they stay here. Ki Ageng Wonolelo built a cottage for his students".

The generosity of Ki Ageng Wonolelo's figure is a reflection of the soul of a hero.

\section{Nationalism}

The value of nationalism in the folklore of Ki Ageng Wonolelo can be seen in a strong figure who tries his best to love his country and comfortable with the construction of a place of worship and a place to gain knowledge. He has a way of thinking and behaving that shows concern for the environment around him. Ki Ageng Wonolelo's love for the country was also shown when he until the end of his life, he was buried in Pondok Wonolelo.

\section{Rewarding Achievements}

The value of appreciating achievement in the folklore of Ki Ageng Wonolelo was shown when Grandma Ki Ageng Wonolelo had more knowledge than Ki Ageng Wonolelo and spurred Ki Ageng Wonolelo to gain more knowledge. One of Ki Ageng Wonolelo's strengths is his intelligence from childhood. Being humble and still appreciating the achievements of others reflects the commendable attitude of Ki Ageng Wonolelo.

\section{Friendly / Communicative}

The value of being friendly or communicative in the folklore of Ki Ageng Wonolelo is found in the way Ki Ageng Wonolelo communicates with his students. Many students wanted to learn from him, his warm hospitality and explanation of the way he taught his students made him respected by his students.

M. Loving Peace

The peace-loving value contained in the folklore of Ki Ageng Wonolelo is implied in the following narrative:

Quote:

...

Translate :

"When Syeh Jumadigeno and Syeh Wasibageno in Wonogiri were meeting Surenggodo and Surenggeno who were fighting chickens, this is not allowed in religious teachings. He cannot accept advice, so fighting is the only way to do the right thingsthen finally Surenggeno lost and became follower of Syeh Jumadigeno and Syeh Wasibageno. "

$\mathrm{He}$ upholds peace, Ki Ageng Wonolelo prefers to advise before fighting because Surengggodo and Surenggeno do not want to listen to his advice and in the end they lose and become the student of Ki Ageng Wonolelo. 


\section{Social care}

The value of social care in the folklore of Ki Ageng Wonolelo was proven when the natural disaster of Mount Merapi bring lava, Grandma Ki Ageng Wonolelo moved to the slopes of Merapi so that the surrounding community would avoid the disaster. This is shown by the following speech:

Quote:

..

Translate :

"When the volcano bring lava, in order to the lava did not flow to the south so that the residents would avoid the disaster, that is the reason of why Prince Blancak Ngoli moved on the slopes of Merapi on the edge of Turgo. After that it was called the Turgo padukuhan". Eyang Ki Ageng Wonolelo who are willing to help the people around the mountain Merapi in order to avoid natural disasters.

\section{Responsible}

The value of responsibility in the folklore of Ki Ageng Wonolelo describes a leader with responsible attitude and behavior towards his followers, namely Surenggodo and Surenggeno. His attitude was shown by following his student who was suddenly thrown to the southeast. As a sense of responsibility for a leader, Ki Ageng Wonolelo do his duties and obligations to protect his followers from any unexpected things.

The development of culture involves some elements: religious system, societal system, or social organization, knowledge system, language, art, livelihood system or economic system, and life tool and technology system [12]. Spiritual quotient can generate idea, energy, value, vision, and motivation to make an individual's life better [13].

\section{Conclusion}

The values of character in the Folklore of Ki Ageng Wonolelo that the writer found are 15 moral values consisting of religious, honest, tolerance, discipline, hard work, creative, independent, democratic, spirit of nationality, nationalism, rewarding achievement, friendly/communicative, peace-loving, social care, and responsibility.

\section{Suggestion}

Due to development of the technological era in modern life, the customs of Indonesian people shift in value. It is not impossible that a shift in values can erase the customs for the young generation who have not been able to anticipate the foreign cultures. Therefore, it is very useful to conduct research on folklore in supporting the national cultural assets.

\section{References}

[1] Ratna, N.K. 2011. Antropologi Sastra, Peranan Unsur-Unsur Kebudayaan dalam Proses Kreatif.Yogyakarta: Pustaka Pelajar. p.165.

[2] Jauss, H.R. 1974. Toward an Aesthetic of Reception. Minneapolis: University of Minnesota.

[3] Endraswara, S. 2003. Falsafah HidupJawa. Yogyakarta: Cakrawala.

[4] Suyadi. 2013. Strategi Pembelajar Pendidikan Karakter. Bandung: Rosdakarya Remaja.

[5] Atar Semi. 1990. Metode Penelitian Sastra. Bandung: Angkasa. 
[6] Umi Thoifah Amalia, Endang Purwaningsih, "Local Wisdom Tourism Development Of Semarang With Tourism Cluster System As An Action For Sustainble Economics Development", Prosiding seminar internasional ELIC 2017, The 1st Education and Language International Conference, Proceedings Center for International Language Development of Unissula.

[7] Sangidu. 2004. Penelitian Sastra: Pendekatan, Teori, Metode, Teknik, dan Kiat. Yogyakarta: Unit Penerbitan Sastra Asia Barat UGM.

[8] Lexy J. Moleong. 2010. Metodologi Penelitian Kualitatif. Bandung: Remaja Rosdakarya.

[9] Levi-Strauss, C. 1963. Structural anthropology. New York: Basic Books Inc. Publisher.

[10] Sartini, “Abstract: Kata Kunci:,” J. Filsafat, vol. 37, no. 2, pp. 111-120, 2004.

[11] M. I. Ahnaf and D. N. Lussier, "Religious Leaders and Elections in the Polarizing Context of Indonesia," Humaniora, vol. 31, no. 3, pp. 227-237, 2019.

[12] Jalaludin Nor Hashimah dan Zaharoh Ahmad, 2011. Metodologi Penelitian Kebudayaan, Jurnal Komunikasi Malaysia. pp. 203-2019.

[13] Sukidi. 2004. Kecerdasan Spiritual. PT. Gramedia Pustaka Utama: Jakarta. 